\title{
Morphological plasticity in the small copepod Oithona similis in the Barents and White Seas
}

\author{
Vladimir G. Dvoretsky*, Alexander G. Dvoretsky
}

Murmansk Marine Biological Institute, Kola Scientific Centre of the Russian Academy of Sciences, Vladimirskaya str. 17, Murmansk 183010, Russia

\begin{abstract}
We investigated the spatial morphological variability of the most abundant small planktonic copepod Oithona similis in the Barents and White Seas. Four areas differing in temperature and salinity were delineated in each sea. The average prosome length increased but relative antennae size decreased in both sexes from south to north in both seas. Antennule length tended to decrease from north to south and from east to west in the White Sea, and from north to south and west to east in the Barents Sea. In both areas examined, the average body size and relative setae length correlated negatively with temperature and positively with salinity, while total antennule length, total number of setae, total setae length and relative antennule length correlated negatively with salinity and positively with temperature. In the Barents Sea, the morphological parameters of O. similis were more significantly correlated with temperature, while those in the White Sea were more strongly correlated with salinity. We suggest that $O$. similis body size and morphological parameter variations along the south-north axis in the Barents and White Seas can be explained by water temperature and salinity variations, respectively, and have an adaptive significance. Our data suggest that food conditions had less effect on body size and morphological variation. Through analysis of morphological parameters over a wide spatial scale, the present study has shown that 3 and 4 groups of $O$. similis were present in the Barents and White Seas, respectively.
\end{abstract}

KEY WORDS: Oithona similis · Body size $\cdot$ Morphology $\cdot$ Temperature effects $\cdot$ Salinity effects Barents Sea $\cdot$ White Sea

Resale or republication not permitted without written consent of the publisher

\section{INTRODUCTION}

Oithona similis Claus 1866 is widely distributed in the Barents and White seas, forming up to 60 to $80 \%$ of the average zooplankton abundance (Prygunkova 1974, Pedersen et al. 1995, Dvoretskii 2007). The species plays an important role in the functioning of pelagic ecosystems. The distribution and life cycle of O. similis were partly studied previously in the Chupa inlet of the White Sea and in the coastal parts of the southern Barents Sea (Prygunkova 1974, Fomin 1978, Dvoretskii 2007). Many aspects of O. similis biology, however, have not been investigated to the same extent. This is particularly true for the morphological variability of the species, especially in the Barents Sea.

A species' morphology generally defines its adaptation to environmental conditions. A complex of oceanographic factors (primarily water temperature and salinity) affects the body organization of marine crustaceans. In some cases, the structure of the organs and their segmentation are connected with the life strategy of the organism (Calow 1977). However, a detailed study of how an organism adapts to changes in its environment is needed if we want to better understand the evolution of body organization. In addition, information concerning the existing morphological variability in copepods is required to understand the mechanisms underlying their adaptations to different conditions, determine their status and importance as food resources in the Arctic seas, and subsequently, specify their role in the functioning of marine ecosystems. The division of copepod species into intraspecific groups also has important implications for the resolution of practical problems. For example, indi- 
vidual populations, subpopulations or groups might serve as indicators of different water masses and hydrological conditions (Raymont 1980). The identification of morphological subgroups may also help in the determination of the potential relationships between recruitment into a population and losses from the population under unfavorable environmental conditions. The investigation of morphological characteristics of aquatic animals is particularly interesting within regions connected by oceanic current systems (Shuvalov 1965).

The Barents and White Seas are characterized by a wide range of hydrological factors that permit the elucidation of spatial trends in the morphological variability of Oithona similis. O. similis individuals from different parts of the Arctic seas can differ markedly in morphology (e.g. body size, shape). It has been proposed that the species is polytypic within the region and is composed of different groups or subpopulations (Shuvalov 1980). In the present study, we tried to test this idea by using numerical taxonomy to look for differences in the population structure. In particular, we tried to delineate subpopulations within the overall population of $O$. similis in the region. We also examined variations in body size and other morphological features of $O$. similis in relation to the water properties of the Barents and White Seas during the summer season.

A

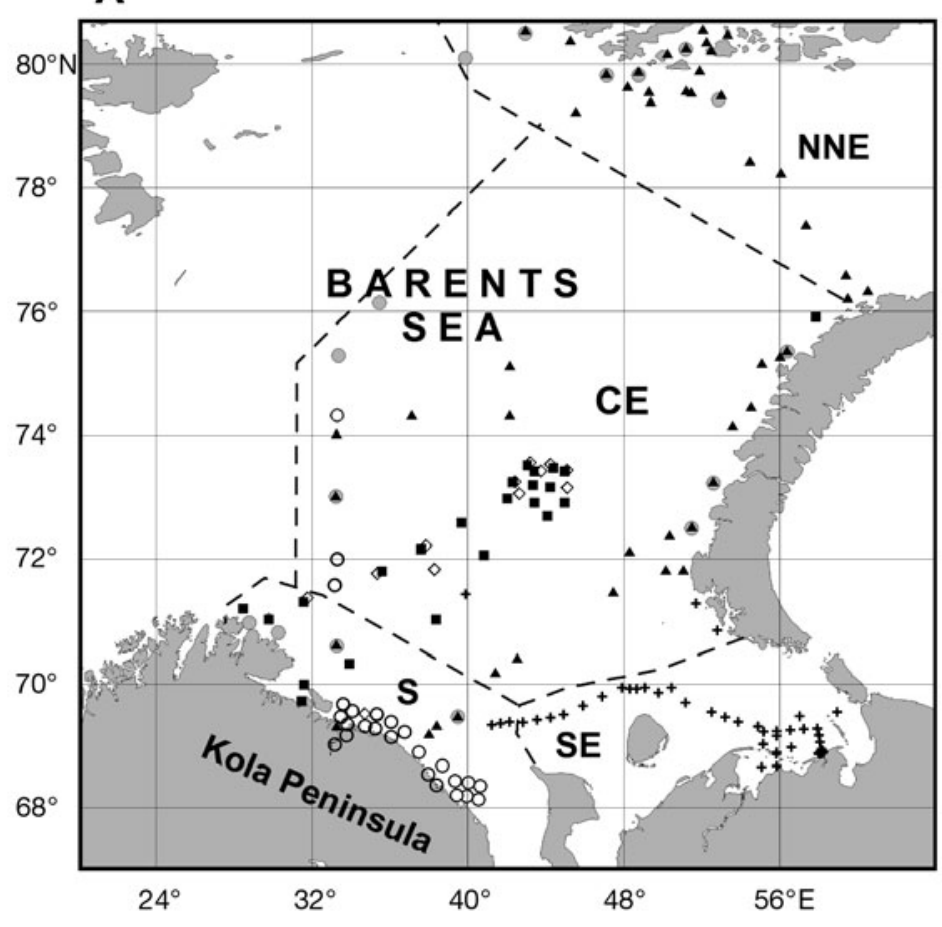

\section{MATERIALS AND METHODS}

Study area. The Barents Sea is a relatively shallow sea (average depth $=230 \mathrm{~m}$ ) located between 70 and $81^{\circ} \mathrm{N}$ on the North European continental shelf (Fig. 1A). Its area, volume, and maximum depth are $1405000 \mathrm{~km}^{2}, 322000 \mathrm{~km}^{3}$, and $600 \mathrm{~m}$, respectively (Dobrovolskiy \& Zalogin 1982). Hydrological conditions of this sea are determined by a combination of Atlantic water in the south and west, and Arctic or mixed water in the north and east (Ingvaldsen et al. 2004). The Atlantic water is characterized by salinities of $\sim 35$ and temperatures of $2^{\circ} \mathrm{C}$ or higher. The Arctic water is typically colder than $0^{\circ} \mathrm{C}$ and has salinities ranging from 34.3 to 34.8 (Schauer et al. 2002). In summer, surface water temperatures range from -1 to $0^{\circ} \mathrm{C}$ in the northern region, and from 8 to $9^{\circ} \mathrm{C}$ in the southern region (Boitsov 2006). Spatial variation in salinity is caused by influxes from the Atlantic, the current regime, ice formation and melting, river run-off, and water mixing. Salinity fluctuates over a wide range during the summer. Low salinity (25.0 to 30.0 ) is observed in the southeastern region of the Barents Sea due to the intensive freshwater influence of the Pechora River. In the other regions, water salinity is 33.0 to 35.0 (Table 1).

The White Sea is a marginal sea of the Arctic Ocean (Fig. 1B). It is joined with the Barents Sea by a shallow,

B

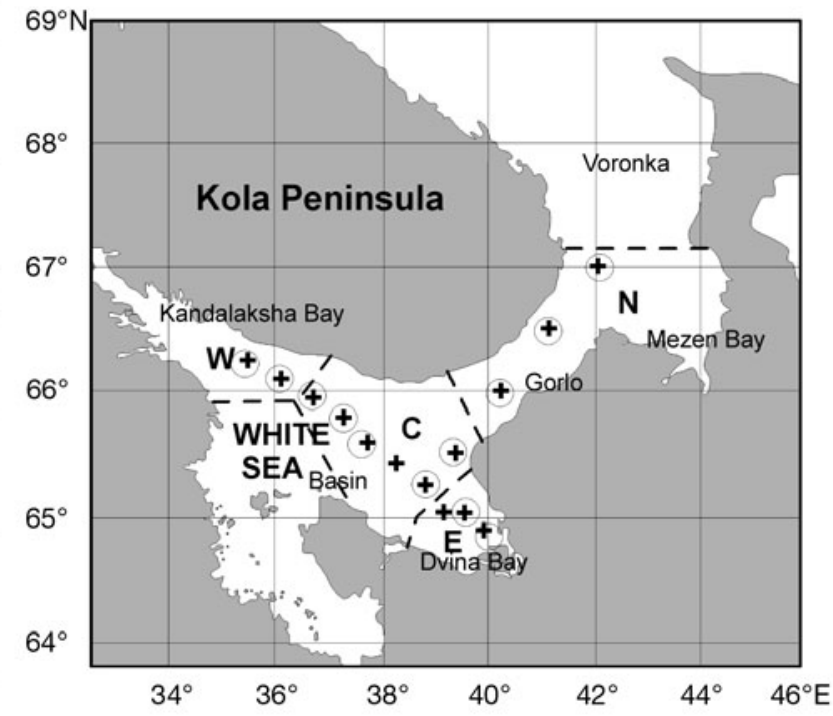

Fig. 1. Location of sampled stations and hydrological areas as defined by cluster analysis in (A) the Barents Sea and (B) the White Sea. Dashed line: delineation into hydrological regions, S: southern, SE: southeastern, CE: central and eastern, NNE: northern and north-

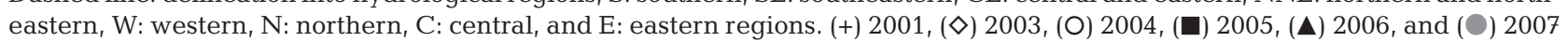


Subsequent analyses, based principally on adult morphology, followed the procedures and terminology of Shuvalov (1980). In Oithona, the body consists of a prosome (cephalothorax) and an abdomen. Each of the antennules (I antennae) has 12 segments and extends to the genital segment in both sexes. The anterior edge of the antennule is well supplied with setae, with additional setae located on the other parts. For each individual, we measured (1) total cephalothorax length (Lc) and (2) total antennule length (La), (3) counted total number of setae on both antennules (Ns), and (4) measured total setae length (Ls) using a stereomicroscope (LOMO ES BIMAM R-11-1, 100× magnification). In addition, we calculated (5) relative antennule length (La/Lc, \%), and (6) relative setae length (Ls/La, \%). Overall, we examined 1450 (450 males and 1000 females) and 4350 (1200 males and 3150 females) individuals from the White and the Barents Seas, respectively.

Calculation of basic descriptive and statistical parameters followed standard methods (Zaks 1976). Differences in morphological parameters of Oithona similis among the regions studied were compared using Kruskal-Wallis tests. When the test was significant, medians for the 4 regions were compared using Bonferroni tests and differences were considered significant if $\mathrm{p}<0.05$. Differences between the morphological parameters of males and females in each of the regions examined were compared using MannWhitney tests. Linear regression analysis was used to determine the relationship between mean morphological characteristics and hydrological factors (average temperature and salinity in the upper $50 \mathrm{~m}$ ) for each station at each region. In addition, canonical correlation was run on the data to detect relationships between the hydrological factors and morphological characteristics of $O$. similis, and to validate linear regression results. Discriminant analyses were used to classify $O$. similis populations into morphological groups. We used the regions defined by cluster analysis as group variables, with the morphological characteristics in each region being used as independent variables. Cluster analysis based on the squared Euclidean complete linkage method was carried out using the morphological characteristics of $O$. similis to test for differences between groups in the regions investigated. We combined data from all cruises and ignored any year-to-year variability in the morphological parameters because the period of the investigation (2000-2007) included only warm years with similar temperature conditions (Boitsov 2006); we assumed no significant variations in morphological variability under similar conditions. According to some previous studies (e.g. Deevey 1960, Hygum et al. 2000), food levels are very important for the growth of copepods. Although phytoplankton concentrations were not measured in our study, we used literature data describing phytoplankton distributions in the Barents and the White Seas during summer (Table 1) to evaluate the relationship between morphological characteristics and food levels.

\section{RESULTS}

\section{Regional delineation}

There were 4 regions delineated in the Barents Sea (Fig. 1A): (1) a southern region (S) along the coast, with deep waters (100 to $300 \mathrm{~m})$, high salinity (>34.3) and temperature $\left(>6.5^{\circ} \mathrm{C}\right)$, and strongly affected by warm Atlantic waters; (2) a southeastern region (SE) with shallow waters (30 to $80 \mathrm{~m}$ ), low salinity (28.3 to 32.8 ) and intermediate temperature $\left(2.0\right.$ to $\left.4.4^{\circ} \mathrm{C}\right)$, and influenced by high freshwater inflow; (3) a central and eastern region (CE) with deep waters (200 to $300 \mathrm{~m}$ ), high salinity (34.0 to 34.7 ) and intermediate surface temperature $\left(1.9\right.$ to $\left.3.6^{\circ} \mathrm{C}\right)$, and characterized by the mixing of Atlantic and Barents Sea waters; and (4) a northern and northeastern region (NNE) with high salinity (33.9 to 34.7 ) and low temperature $\left(-0.5\right.$ to $\left.+2{ }^{\circ} \mathrm{C}\right)$, and influenced by cold Arctic waters.

Four regions could be also be delineated in the White Sea (Fig. 1B): (1) a northern region (N) with shallow waters $(20$ to $70 \mathrm{~m})$, low temperature $\left(<6.5^{\circ} \mathrm{C}\right)$ and high salinity (28.3 to 30.2 ); (2) a central region (C) with deep waters (100 to $200 \mathrm{~m})$, and intermediate temperature $\left(6.7\right.$ to $\left.8.6^{\circ} \mathrm{C}\right)$ and salinity (26.9 to 27.4$)$; (3) a western region (W) with deep waters (150 to $200 \mathrm{~m}$ ), and intermediate temperature $\left(8.0\right.$ to $\left.8.5^{\circ} \mathrm{C}\right)$ and salinity (27.1 to 27.2$)$; and (4) an eastern region (E) with shallow waters (15 to $65 \mathrm{~m})$, high temperature (6.9 to $16.5^{\circ} \mathrm{C}$ ) and low salinity (23.4 to 27.9$)$.

\section{Prosome length variations}

Size distributions of Oithona similis varied in the different regions of the Barents Sea (Fig. 2). In the south region, most of the males (35.1\%) had a prosome length (PL) of $405 \mu \mathrm{m}$. Individuals with PL of $450 \mu \mathrm{m}(28.0 \%)$ and $465 \mu \mathrm{m}(36.8 \%)$ prevailed among females. In the Pechora Sea (SE region), specimens with PL of $375 \mu \mathrm{m}$ $(25.2 \%)$ and $405 \mu \mathrm{m}(20.2 \%)$ dominated among males, while individuals with PL of $480 \mu \mathrm{m}$ (25.6\%) dominated among females. In the central and eastern region, we observed a unimodal size distribution among males, with specimens $420 \mu \mathrm{m}$ long occurring most frequently, and accounting for $25 \%$ of the specimens. The distribution of females, however, was bimodal (495 $\mu \mathrm{m}, 26.8 \%$; 


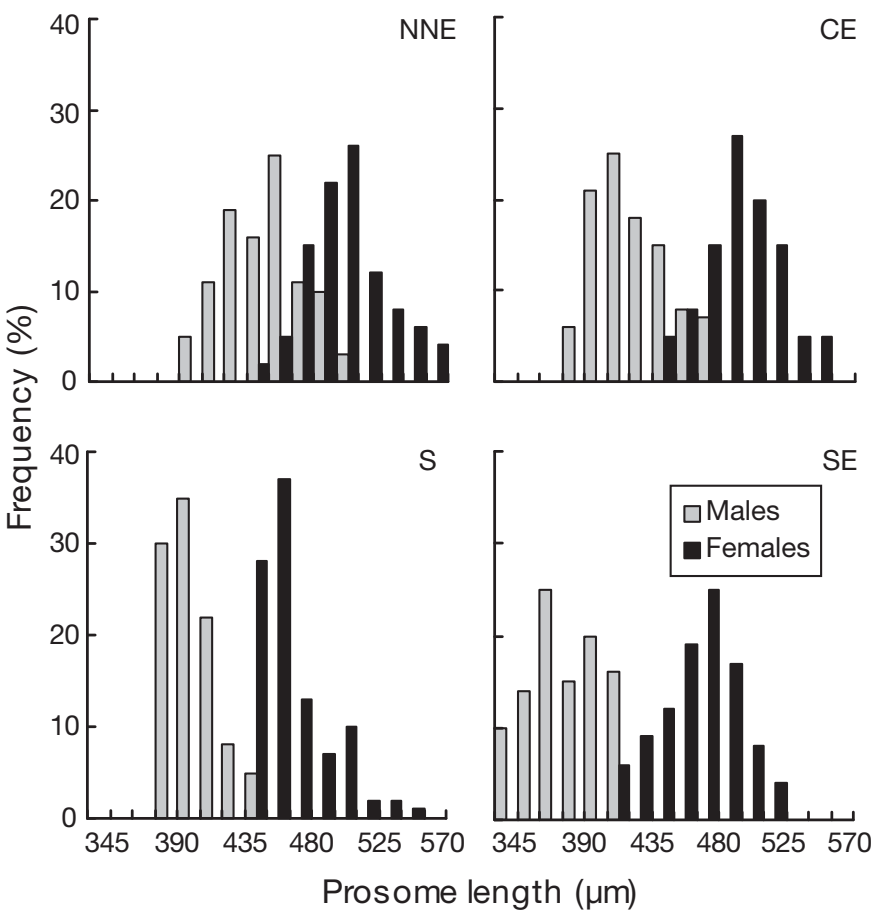

Fig. 2. Oithona similis. Prosome length distributions of males and females from various Barents Sea regions. S: southern, SE: southeastern, CE: central and eastern, and NNE: northern and northeastern regions

$510 \mu \mathrm{m}, 20.4 \%)$. In the north and northeastern region, the modal PL were $465 \mu \mathrm{m}(25.1 \%)$ for males and $510 \mu \mathrm{m}(26.4 \%)$ for females. In all parts, some overlapping of the female size spectrum was observed. The average PL of both sexes increased from the south to the north (Fig. 3). Significant differences in the mean cephalothorax length were revealed for both males and females (Table 3). Multiple pairwise comparisons of male body sizes in each region of the Barents Sea showed differences in all cases. Similar results were obtained for females except between the southern and southeastern regions (Fig. 3). PL of females were significantly larger than those of males (Table 4).

Oithona similis size distributions in the White Sea are presented in Fig. 4. The PL of females varied from 420 to $555 \mu \mathrm{m}$ (modal size $=465 \mu \mathrm{m}$ in all cases). In males, cephalothorax length ranged from 375 to $450 \mu \mathrm{m}_{i}$ the distributions were unimodal in each region, with modes of $435 \mu \mathrm{m}(23.4 \%)$ in the northern region, $390 \mu \mathrm{m}(26.2 \%)$ in the central region, and $420 \mu \mathrm{m}$ ( 26.3 and $30.0 \%$, respectively) in the eastern and western regions. The mean size of males was similar in all regions (Fig. 5); however, significant differences in the mean length of males were seen between some regions (Table 3, Fig. 5). Similar sizes were observed for the northern and eastern regions, and the northern and central regions. The average size of

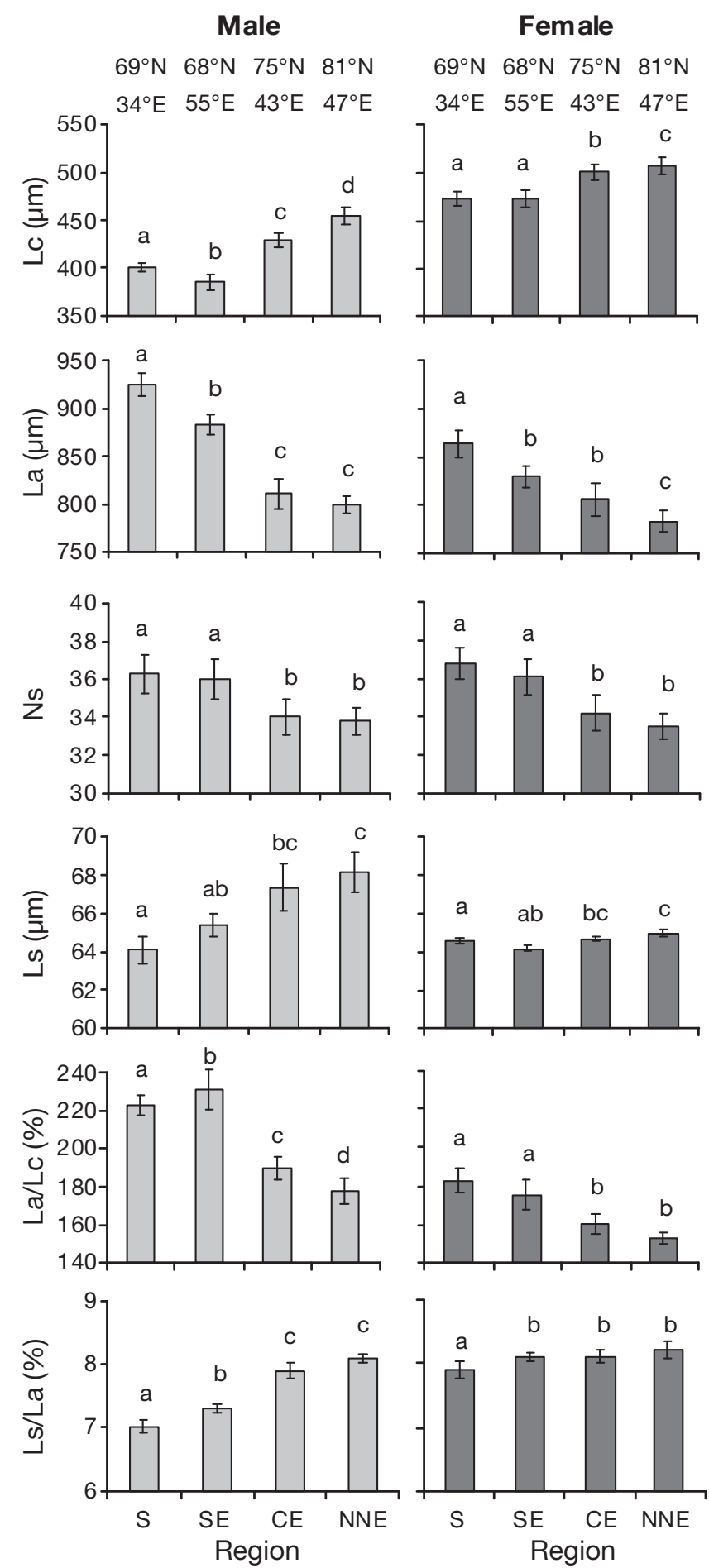

Fig. 3. Oithona similis. Latitudinal trends in morphological variability of males and females (mean $\pm 95 \% \mathrm{CI}$ ) in the Barents Sea. Means within a panel with the same letter are not significantly different ( $p>0.05$, Bonferroni's test for medians). $\mathrm{S}$ : southern, SE: southeastern, CE: central and eastern, and NNE: northern and northeastern regions. Lc: total cephalothorax length, La: total antennule length, Ns: total number of setae on both antennules, Ls: total setae length, La/Lc: relative antennule length, and Ls/La: relative setae length 
Table 3. Oithona similis. Comparisons of morphological characteristics among the regions studied in the Barents and White Seas (Kruskal-Wallis test). H: Kruskal-Wallis 1-way ANOVA by ranks

\begin{tabular}{|c|c|c|c|c|}
\hline & \multicolumn{2}{|c|}{ Barents Sea } & \multicolumn{2}{|c|}{ White Sea } \\
\hline & $H$ & $\mathrm{p}$ & $H$ & $\mathrm{p}$ \\
\hline \multicolumn{5}{|l|}{ Male } \\
\hline Total cephalothorax length (Lc) & 1090.74 & $<0.001$ & 18.97 & $<0.001$ \\
\hline Total antennule length (La) & 142.63 & $<0.001$ & 136.89 & $<0.001$ \\
\hline Total number of setae on both antennules (Ns) & 27.51 & $<0.001$ & 80.85 & $<0.001$ \\
\hline Total setae length (Ls) & 32.90 & $<0.001$ & 52.51 & $<0.001$ \\
\hline Relative antennule length (La/Lc) & 184.80 & $<0.001$ & 57.58 & $<0.001$ \\
\hline Relative setae length (Ls/La) & 140.53 & $<0.001$ & 137.08 & $<0.001$ \\
\hline \multicolumn{5}{|l|}{ Female } \\
\hline Total cephalothorax length (Lc) & 1168.68 & $<0.001$ & 8.46 & 0.037 \\
\hline Total antennule length (La) & 74.95 & $<0.001$ & 100.23 & $<0.001$ \\
\hline Total number of setae on both antennules (Ns) & 32.59 & $<0.001$ & 35.49 & $<0.001$ \\
\hline Total setae length (Ls) & 47.22 & $<0.001$ & 86.06 & $<0.001$ \\
\hline Relative antennule length (La/Lc) & 110.51 & $<0.001$ & 58.06 & $<0.001$ \\
\hline Relative setae length (Ls/La) & 13.35 & 0.004 & 130.14 & $<0.001$ \\
\hline
\end{tabular}

Table 4. Oithona similis. Comparisons of morphological parameters (Mann-Whitney tests) between males (M) and females (F) in each region studied in the Barents and White Seas. Barents Sea: S (southern), SE (southeastern), CE (central and eastern), and NNE (northern and northeastern) regions. White Sea: N (northern), W (western), C (central), and E (eastern) regions. ( $\left.{ }^{*}\right) \mathrm{p}<0.05$, $\left({ }^{* *}\right) \mathrm{p}<0.001$. For parameter abbreviations see Table 3

\begin{tabular}{|c|c|c|c|c|c|c|c|c|}
\hline & \multicolumn{4}{|c|}{ - Barents Sea - } & \multicolumn{4}{|c|}{ White Sea- } \\
\hline & $\mathrm{S}$ & $\mathrm{SE}$ & $\mathrm{CE}$ & NNE & $\mathrm{N}$ & W & $\mathrm{C}$ & E \\
\hline Lc $(\mu \mathrm{m})$ & $\mathrm{M}<\mathrm{F}^{* *}$ & $\mathrm{M}<\mathrm{F}^{* *}$ & $\mathrm{M}<\mathrm{F}^{* *}$ & $\mathrm{M}<\mathrm{F}^{* *}$ & $\mathrm{M}<\mathrm{F}^{* *}$ & $\mathrm{M}<\mathrm{F}^{* *}$ & $\mathrm{M}<\mathrm{F}^{* *}$ & $\mathrm{M}<\mathrm{F}^{* *}$ \\
\hline La $(\mu \mathrm{m})$ & $\mathrm{M}<\mathrm{F}^{* *}$ & $\mathrm{M}<\mathrm{F}^{* *}$ & $\mathrm{M}<\mathrm{F}^{* *}$ & $\mathrm{M}<\mathrm{F}^{* *}$ & $\mathrm{M}<\mathrm{F}^{* *}$ & $\mathrm{M}<\mathrm{F}^{* *}$ & $\mathrm{M}<\mathrm{F}^{* *}$ & $\mathrm{M}<\mathrm{F}^{* *}$ \\
\hline $\mathrm{Ns}$ & $\mathrm{M}=\mathrm{F}$ & $\mathrm{M}=\mathrm{F}$ & $\mathrm{M}=\mathrm{F}$ & $\mathrm{M}=\mathrm{F}$ & $\mathrm{M}=\mathrm{F}$ & $\mathrm{M}<\mathrm{F}^{* *}$ & $\mathrm{M}<\mathrm{F}^{* *}$ & $\mathrm{M}<\mathrm{F}^{* *}$ \\
\hline Ls $(\mu \mathrm{m})$ & $\mathrm{M}>\mathrm{F}^{* *}$ & $\mathrm{M}>\mathrm{F}^{* *}$ & $\mathrm{M}>\mathrm{F}^{*}$ & $\mathrm{M}=\mathrm{F}$ & $\mathrm{M}=\mathrm{F}$ & $\mathrm{M}>\mathrm{F}^{* *}$ & $\mathrm{M}>\mathrm{F}^{* *}$ & $\mathrm{M}=\mathrm{F}$ \\
\hline $\mathrm{La} / \mathrm{Lc}(\%)$ & $\mathrm{M}>\mathrm{F}^{* *}$ & $\mathrm{M}>\mathrm{F}^{* *}$ & $\mathrm{M}>\mathrm{F}^{* *}$ & $\mathrm{M}>\mathrm{F}^{* *}$ & $\mathrm{M}>\mathrm{F}^{* *}$ & $\mathrm{M}>\mathrm{F}^{* *}$ & $\mathrm{M}=\mathrm{F}$ & $\mathrm{M}>\mathrm{F}^{* *}$ \\
\hline Ls/La (\%) & $\mathrm{M}<\mathrm{F}^{* *}$ & $\mathrm{M}<\mathrm{F}^{* *}$ & $\mathrm{M}<\mathrm{F}^{*}$ & $\mathrm{M}=\mathrm{F}$ & $\mathrm{M}>\mathrm{F}^{* *}$ & $\mathrm{M}=\mathrm{F}$ & $\mathrm{M}>\mathrm{F}^{* *}$ & $\mathrm{M}=\mathrm{F}$ \\
\hline
\end{tabular}

females also varied significantly among regions; however, difference between medians was found only for the northern and eastern parts. Females were significantly larger than males (Table 4).

\section{Variations in antennule morphology}

Trends in morphological parameters of Oithona similis in the different regions of the Barents Sea are presented in Fig. 3. All the parameters fluctuated strongly for $O$. similis females and males. We noted clear latitudinal trends in antennule length, number of setae, and relative antennule length, with each parameter decreasing with increasing latitude for both males and females (Table 3, Fig. 3). The highest values were noted in the southern region except for the relative length of antennules in males. The smallest values were observed for the NNE region. The relative setae length, in contrast, weakly increased from the south to the north. In most cases, parameters observed in adjacent regions (S-SE, CE-NNE) were similar (Fig. 3).

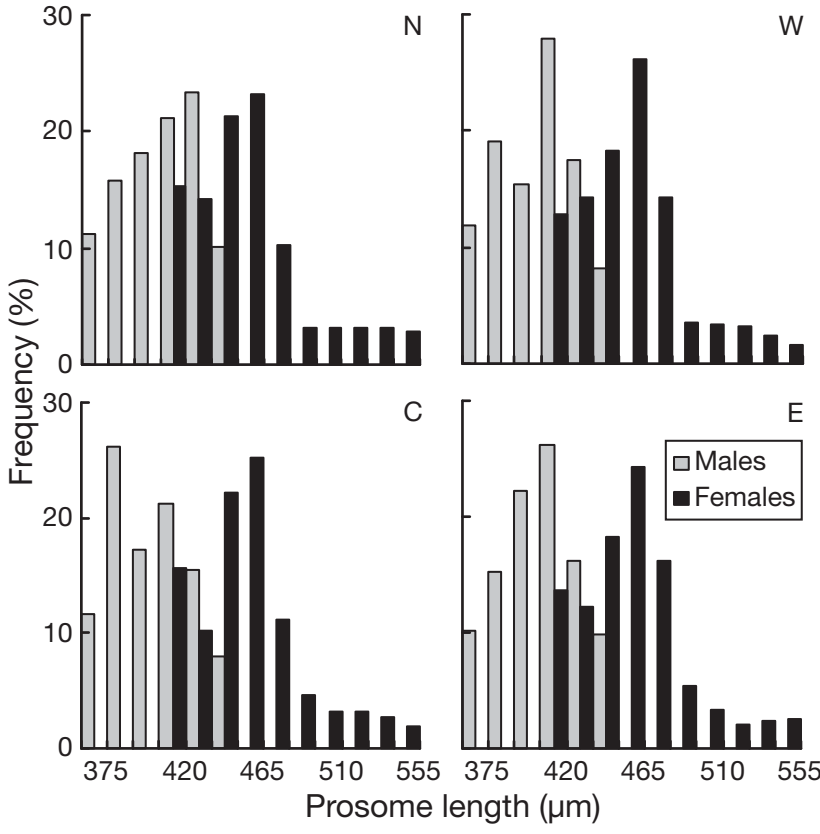

Fig. 4. Oithona similis. Prosome length distributions of males and females from various White Sea regions. N: northern, $\mathrm{E}$ : eastern, C: central, and $\mathrm{W}$ : western regions 
Male

$67^{\circ} \mathrm{N} 65^{\circ} \mathrm{N} 66^{\circ} \mathrm{N} 65^{\circ} \mathrm{N}$ $42^{\circ} \mathrm{E} \quad 38^{\circ} \mathrm{E} \quad 36^{\circ} \mathrm{E} \quad 39^{\circ} \mathrm{E}$
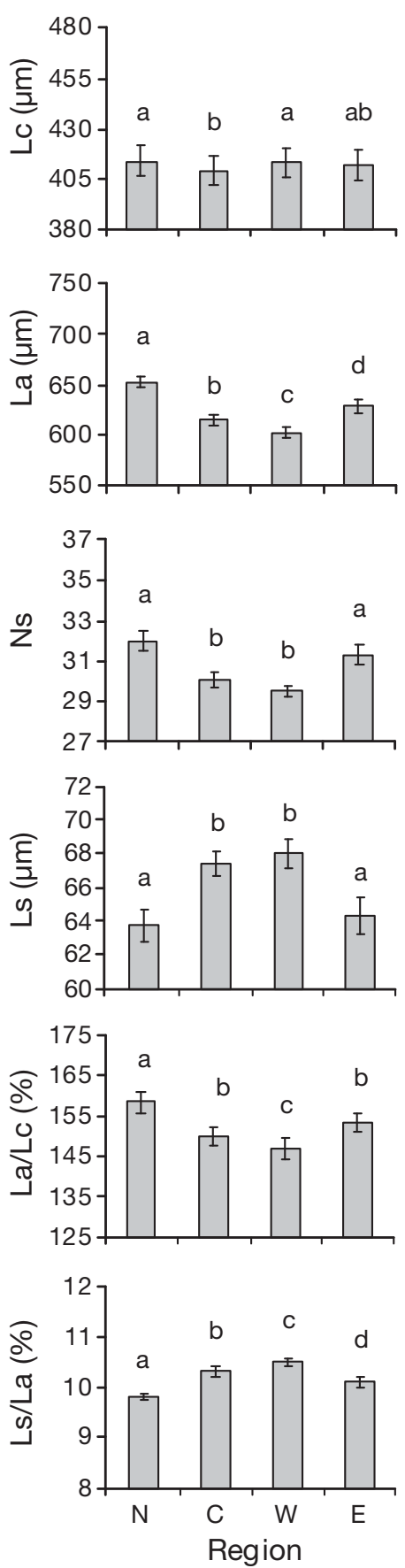

Female

$67^{\circ} \mathrm{N} 65^{\circ} \mathrm{N} 66^{\circ} \mathrm{N} 65^{\circ} \mathrm{N}$ $42^{\circ} \mathrm{E} \quad 38^{\circ} \mathrm{E} \quad 36^{\circ} \mathrm{E} \quad 39^{\circ} \mathrm{E}$
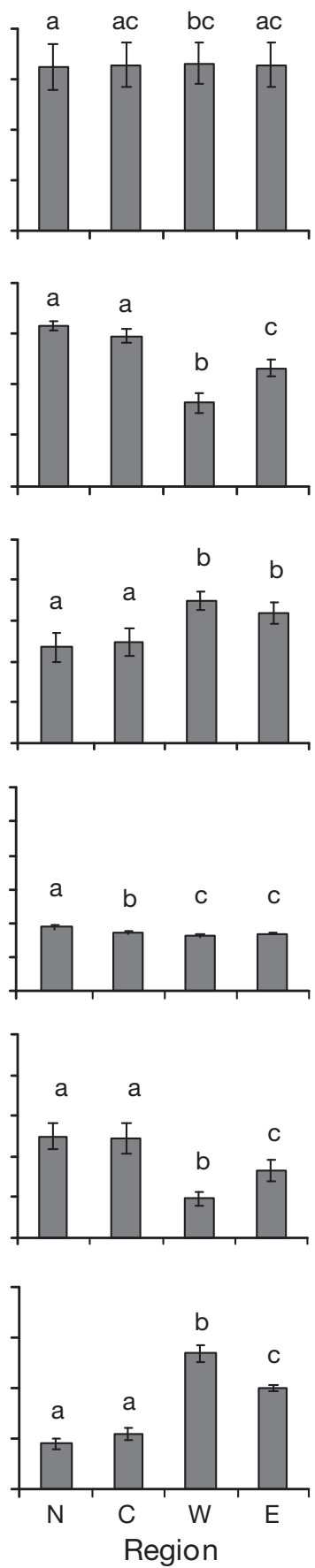

Fig. 5. Oithona similis. Latitudinal trends in morphological variability of males and females (mean $\pm 95 \% \mathrm{CI}$ ) in the White Sea. Means within a panel with the same letter are not significantly different ( $p>0.05$, Bonferroni's test for medians). $\mathrm{N}$ : northern, E: eastern, C: central, and W: western regions. LC: total cephalothorax length, La: total antennule length, Ns: total number of setae on both antennules, Ls: total setae length, La/Lc: relative antennule length, and Ls/La: relative setae length
There were some differences in antennule morphology between males and females in the Barents Sea (Table 4). Males had significantly smaller antennules than females in each of the sites examined, in accordance with the larger size of the females. A similar tendency was noted for relative setae length. In contrast, males had significantly larger setae lengths and relative antennule lengths. In all regions of the Barents Sea, the number of setae in males was not significantly different from that in females.

In the White Sea, significant variability in the morphological parameters of Oithona similis was also observed (Table 3, Fig. 5). From the northern to the central region and from the eastern to the western region, we observed decreases in antennule length, relative antennule length and numbers of setae in males (Fig. 5). In females, we contrastingly found similar values of these characteristics in neighboring regions $(\mathrm{N}-\mathrm{C})$, although in the eastern and western regions the parameters differed significantly, except for in number of setae (Fig. 5). Setae length and relative setae length had a reverse pattern from that of the other morphological parameters. Both parameters increased from the northern to the central and from the eastern to the western region except for female setae lengths in the case of the E-W comparison (Fig. 5).

Similar to the Barents Sea, males had smaller antennules than females in the White Sea. Male relative antennule lengths, setae lengths and relative setae lengths were larger than those of females with some exceptions. Setae numbers were conversely higher in females (Table 4).

Using discriminant analysis, 3 and 4 morphological groups of Oithona similis were delineated in the Barents and White Seas, respectively (Fig. 6a). Cluster analysis showed significant differences between groups in the Barents and White Seas (Fig. 6b).

\section{Relationships between hydrological conditions and morphological variation}

There was a weak correlation between water salinity and the PL of Oithona similis in the Barents Sea (Table 5, Fig. 7). Morphological parameters of $O$. similis were negatively correlated with water salinity. There were no significant correlations with absolute antennule length and the relative setae length of males, and relative antennule length of females (Table 5, Fig. 7). All of the morphological characteristics measured had a clear correlation with water temperature. Body size and relative setae lengths were negatively correlated with temperature, while the numbers of setae, the absolute setae length, and the absolute and relative antennule lengths were positively correlated with temperature (Table 5, Fig. 8). 

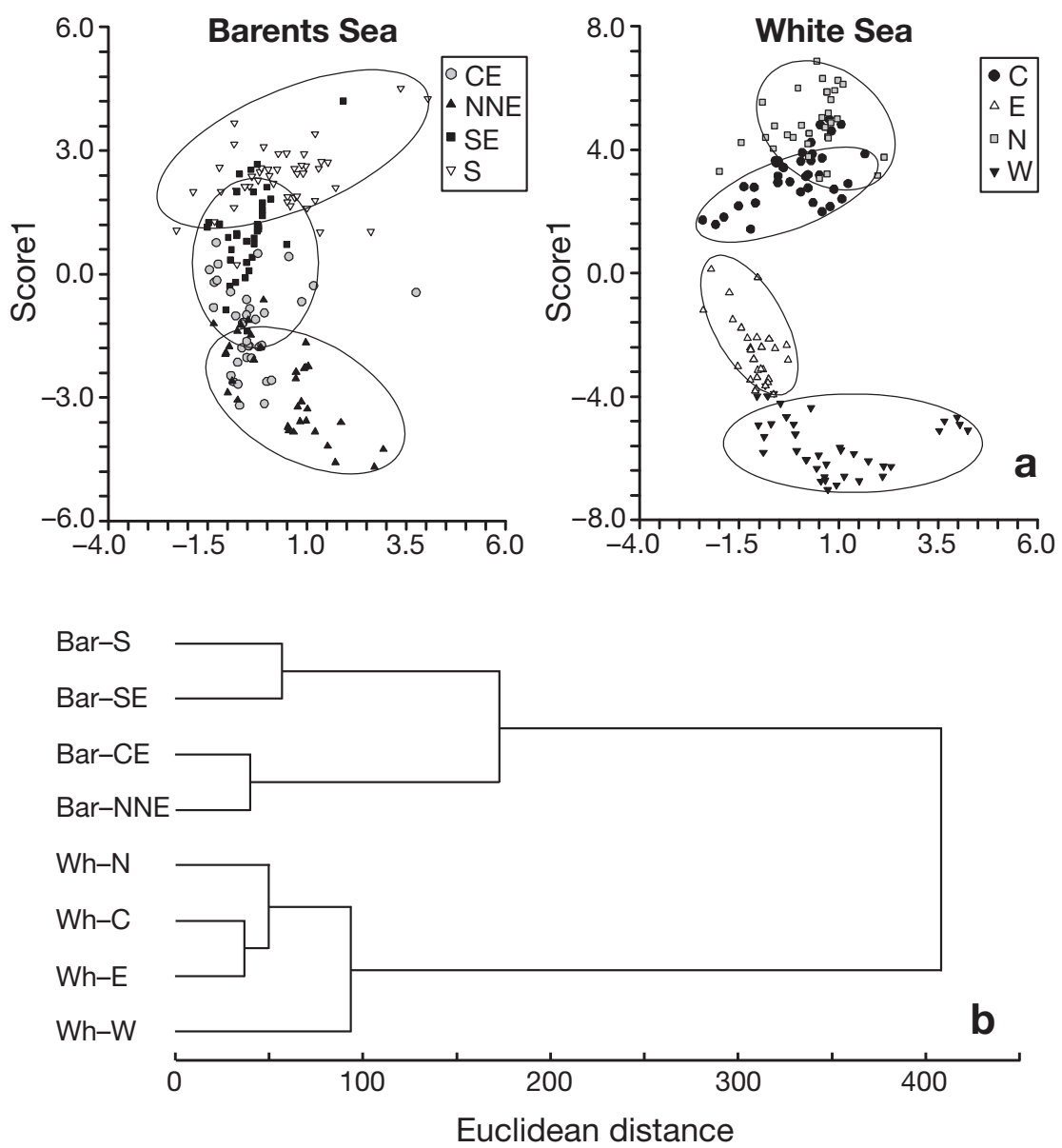

Fig. 6. Oithona similis. Results of discriminant analyses based on prosome lengths and morphological characteristics in the Barents (Bar-) and White (Wh-) Seas. Regions defined as in Fig. 1

In the White Sea, morphological characteristics of Oithona similis were more strongly correlated with salinity (Table 6, Fig. 7). The number of setae and the absolute and relative antennule lengths were negatively correlated with salinity; all other parameters were positively correlated with salinity (Table 6, Fig. 7). We did not observe a clear correlation between salinity and the absolute setae lengths and relative antennule lengths in females. The influence of temperature on body size and morphological parameters was similar to that observed in the Barents Sea; thus, relative antennule lengths in females were negatively correlated with temperature, and there was no relationship between temperature and relative setae length in females (Table 6, Fig. 8).

\section{DISCUSSION}

\section{Prosome length variations}

There are no existing data concerning spatial variations in male body size of Oithona similis in the Barents and White Seas. However, some data on female size variation in Arctic regions is available (Shuvalov 1965, Nielsen et al. 2002, Dvoretskii 2007). We found

Table 5. Oithona similis. Linear and canonical correlations of morphological characteristics with physical variables in the Barents Sea. For abbreviations see Fig. 5

\begin{tabular}{|c|c|c|c|c|c|c|c|c|c|}
\hline & \multicolumn{2}{|c|}{$\begin{array}{c}\text { Phytoplankton }\left(\mathrm{mg} \mathrm{l}^{-1}\right) \\
\mathrm{n}=8\end{array}$} & \multicolumn{2}{|c|}{$\begin{array}{c}\text { Linear correlation- } \\
\text { Temperature }\left({ }^{\circ} \mathrm{C}\right) \\
n=100\end{array}$} & \multicolumn{2}{|c|}{$\begin{array}{l}\text { Salinity } \\
\mathrm{n}=100\end{array}$} & \multicolumn{3}{|c|}{$\begin{array}{c}\text { Canonical correlation } \\
\text { Temperature }+ \text { salinity } \\
\mathrm{n}=100\end{array}$} \\
\hline & $\mathrm{r}$ & $\mathrm{p}$ & $\mathrm{r}$ & $\mathrm{p}$ & $\mathrm{r}$ & $\mathrm{p}$ & $\mathrm{r}$ & $\mathrm{R}^{2}$ & $\mathrm{p}$ \\
\hline \multicolumn{10}{|l|}{ Male } \\
\hline Lc $(\mu \mathrm{m})$ & 0.070 & 0.930 & -0.846 & $<0.001$ & 0.271 & 0.006 & 0.846 & 0.716 & $<0.001$ \\
\hline La $(\mu \mathrm{m})$ & -0.219 & 0.781 & 0.727 & $<0.001$ & -0.162 & 0.108 & 0.731 & 0.535 & $<0.001$ \\
\hline Ns & -0.328 & 0.672 & 0.991 & $<0.001$ & -0.365 & $<0.001$ & 0.991 & 0.983 & $<0.001$ \\
\hline Ls $(\mu \mathrm{m})$ & -0.166 & 0.834 & 0.973 & $<0.001$ & 0.419 & $<0.001$ & 0.978 & 0.957 & $<0.001$ \\
\hline $\mathrm{La} / \mathrm{Lc}(\%)$ & -0.023 & 0.977 & 0.823 & $<0.001$ & -0.223 & 0.026 & 0.825 & 0.680 & $<0.001$ \\
\hline Ls/Lc (\%) & -0.309 & 0.691 & -0.685 & $<0.001$ & 0.154 & 0.127 & 0.690 & 0.476 & $<0.001$ \\
\hline \multicolumn{10}{|l|}{ Female } \\
\hline Lc $(\mu \mathrm{m})$ & 0.278 & 0.722 & -0.851 & $<0.001$ & 0.247 & 0.013 & 0.852 & 0.725 & $<0.001$ \\
\hline La $(\mu \mathrm{m})$ & -0.406 & 0.594 & 0.883 & $<0.001$ & -0.273 & 0.006 & 0.883 & 0.779 & $<0.001$ \\
\hline Ns & -0.390 & 0.610 & 0.772 & $<0.001$ & -0.311 & 0.002 & 0.774 & 0.599 & $<0.001$ \\
\hline Ls $(\mu \mathrm{m})$ & -0.528 & 0.472 & 0.882 & $<0.001$ & 0.293 & 0.006 & 0.855 & 0.732 & $<0.001$ \\
\hline $\mathrm{La} / \mathrm{Lc}(\%)$ & -0.155 & 0.845 & 0.677 & $<0.001$ & -0.182 & 0.071 & 0.678 & 0.460 & $<0.001$ \\
\hline Ls/Lc (\%) & 0.128 & 0.872 & -0.803 & $<0.001$ & 0.232 & 0.020 & 0.804 & 0.646 & $<0.001$ \\
\hline
\end{tabular}



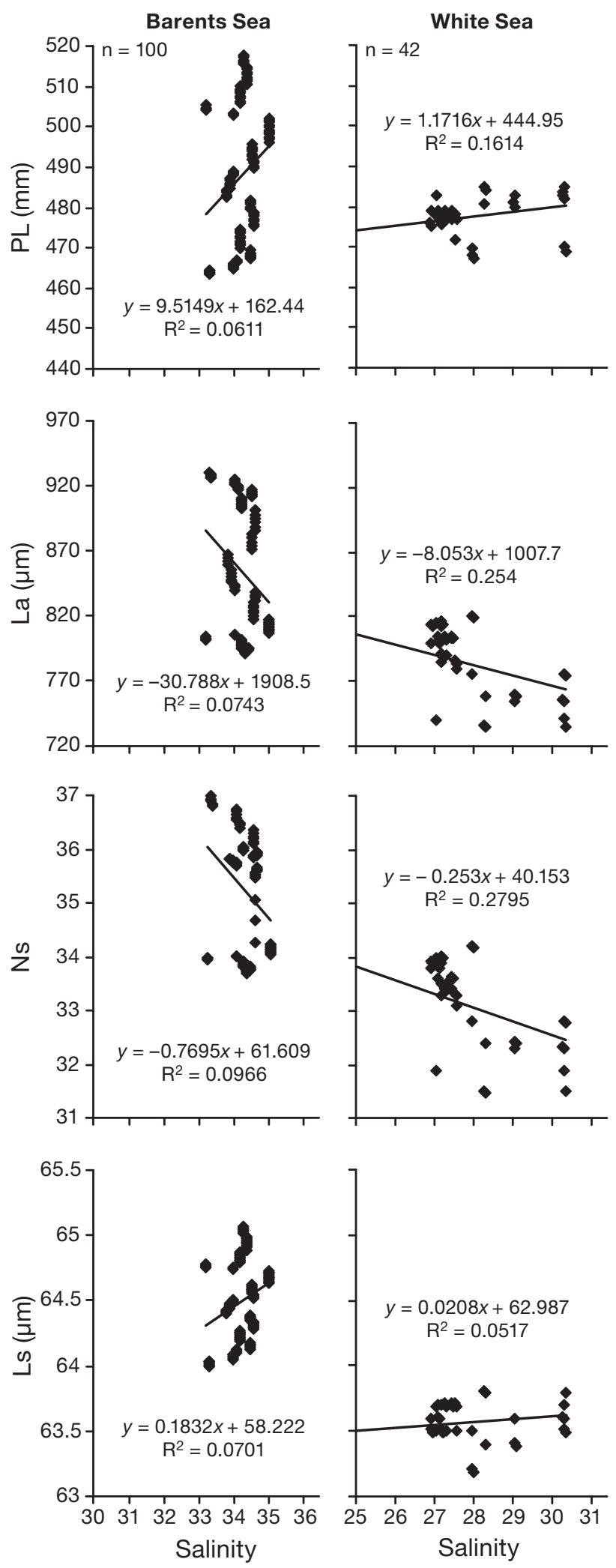

Fig. 7. Oithona similis. Plots of linear correlations between main average morphological characteristics of females and water salinity in the Barents and White Seas. Note different salinity levels. PL: prosome length; other abbreviations: see Fig. 5
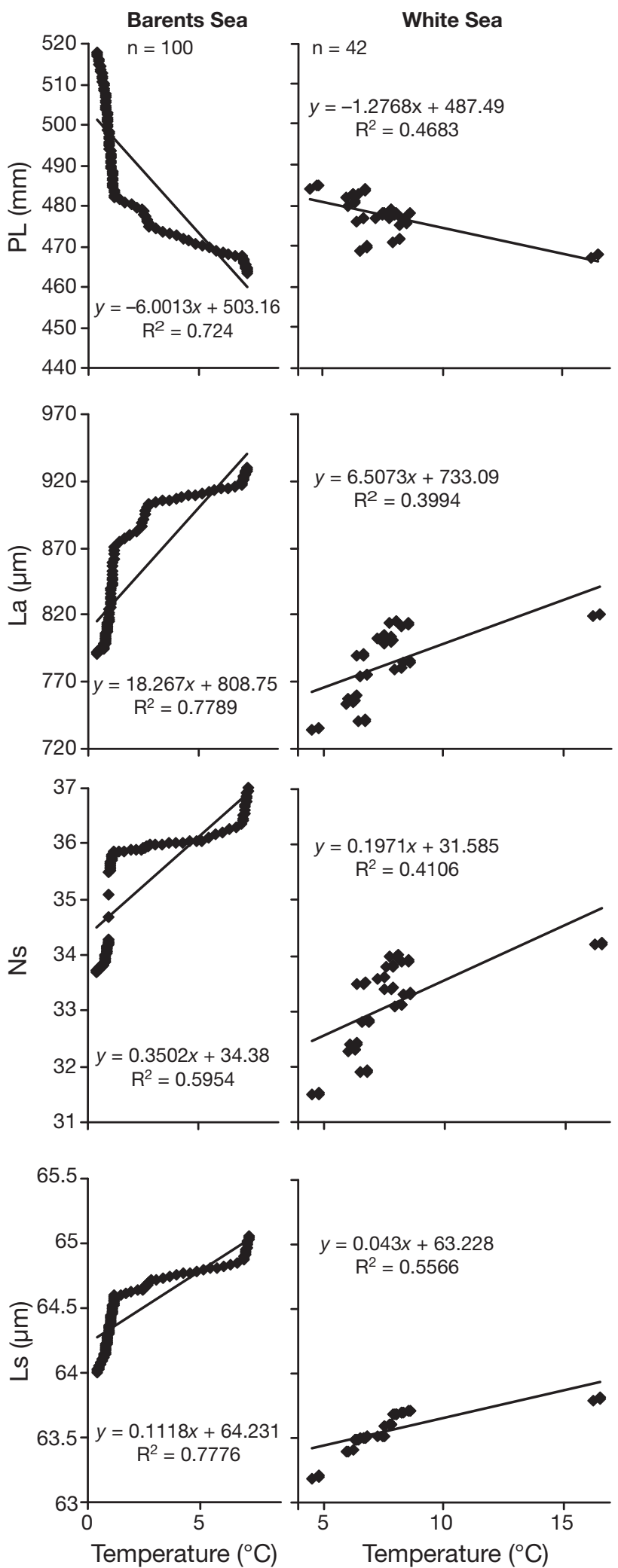

Fig. 8. Oithona similis. Plots of linear correlations between main average morphological characteristics of females and water temperature in the Barents and White Seas. PL: prosome length; other abbreviations: see Fig. 5 
Table 6. Oithona similis. Linear and canonical correlations of morphological characteristics with physical variables in the White Sea. For abbreviations see Fig. 5

\begin{tabular}{|c|c|c|c|c|c|c|c|c|c|}
\hline & \multicolumn{2}{|c|}{$\begin{array}{c}\text { Phytoplankton }\left(\mathrm{mg} \mathrm{l}^{-1}\right) \\
\mathrm{n}=8\end{array}$} & \multicolumn{2}{|c|}{$\begin{array}{c}\text { Linear correlation } \\
\text { Temperature }\left({ }^{\circ} \mathrm{C}\right) \\
n=42\end{array}$} & \multicolumn{2}{|c|}{$\begin{array}{l}\text { Salinity } \\
\mathrm{n}=42\end{array}$} & \multicolumn{3}{|c|}{$\begin{array}{c}\text { Canonical correlation } \\
\text { Temperature + salinity } \\
\mathrm{n}=42\end{array}$} \\
\hline & $\mathrm{r}$ & $\mathrm{p}$ & $\mathrm{r}$ & $\mathrm{p}$ & $\mathrm{r}$ & $\mathrm{p}$ & $\mathrm{r}$ & $\mathrm{R}^{2}$ & $\mathrm{p}$ \\
\hline \multicolumn{10}{|l|}{ Male } \\
\hline $\mathrm{Lc}(\mu \mathrm{m})$ & 0.473 & 0.527 & -0.614 & $<0.001$ & 0.783 & $<0.001$ & 0.791 & 0.625 & $<0.001$ \\
\hline $\mathrm{La}(\mu \mathrm{m})$ & 0.154 & 0.846 & 0.550 & $<0.001$ & -0.805 & $<0.001$ & 0.871 & 0.759 & $<0.001$ \\
\hline Ns & 0.342 & 0.658 & 0.781 & $<0.001$ & -0.914 & $<0.001$ & 0.923 & 0.853 & $<0.001$ \\
\hline Ls $(\mu \mathrm{m})$ & -0.514 & 0.486 & 0.652 & $<0.001$ & 0.577 & $<0.001$ & 0.670 & 0.448 & $<0.001$ \\
\hline $\mathrm{La} / \mathrm{Lc}(\%)$ & 0.081 & 0.919 & 0.641 & $<0.001$ & -0.832 & $<0.001$ & 0.855 & 0.730 & $<0.001$ \\
\hline Ls/Lc (\%) & -0.279 & 0.721 & -0.643 & $<0.001$ & 0.765 & $<0.001$ & 0.769 & 0.591 & $<0.001$ \\
\hline \multicolumn{10}{|l|}{ Female } \\
\hline $\mathrm{Lc}(\mu \mathrm{m})$ & -0.292 & 0.708 & -0.684 & $<0.001$ & 0.402 & 0.009 & 0.771 & 0.595 & $<0.001$ \\
\hline La $(\mu \mathrm{m})$ & -0.443 & 0.557 & 0.632 & $<0.001$ & -0.504 & 0.001 & 0.899 & 0.809 & $<0.001$ \\
\hline $\mathrm{Ns}$ & 0.569 & 0.431 & 0.641 & $<0.001$ & -0.529 & $<0.001$ & 0.919 & 0.844 & $<0.001$ \\
\hline Ls $(\mu \mathrm{m})$ & -0.105 & 0.895 & 0.746 & $<0.001$ & 0.227 & 0.153 & 0.714 & 0.509 & $<0.001$ \\
\hline $\mathrm{La} / \mathrm{Lc}(\%)$ & -0.464 & 0.536 & -0.594 & $<0.001$ & 0.050 & 0.756 & 0.601 & 0.362 & $<0.001$ \\
\hline $\mathrm{Ls} / \mathrm{Lc}(\%)$ & -0.629 & 0.371 & 0.267 & 0.087 & -0.405 & 0.009 & 0.310 & 0.096 & 0.147 \\
\hline
\end{tabular}

that female PL varied from 450 to $570 \mu \mathrm{m}$ in the Barents Sea. The large individuals are likely the female survivors of the fall generation of the previous year. It was observed by Shuvalov (1980) that the spring females are larger. Shuvalov speculated that this was due to favorable food conditions. In the White Sea, female PL ranged from 660 to $790 \mu \mathrm{m}$ in the spring and from 750 to $880 \mu \mathrm{m}$ in the fall (Shuvalov 1965). Two different size-morphological forms of $O$. similis were delineated by Shuvalov (1975) based on the analysis of size composition and body configuration in the Atlantic and White Sea and in the Arctic and Okhotsk Sea: the Atlantic-White Sea group included the North Atlantic population with a modal body size for females of $\sim 730 \mu \mathrm{m}$, and the White Sea population with a modal female body size of $700 \mu \mathrm{m}$; the Arctic-Okhotsk Sea group consisted of Arctic populations with a modal body size of $970 \mu \mathrm{m}$, and an Okhotsk Sea population with a modal body size of $850 \mu \mathrm{m}$. We found that 3 intraspecific groups of $O$. similis could be distinguished in the southern, central and northern sectors of the Barents Sea (Fig. 6). In the southern region, the $O$. similis population is intermediate in female prosome modal size $(480 \mu \mathrm{m})$ between the small boreal form and the large Arctic form. Populations of northern and northeastern regions of the Barents Sea with a modal female PL of $510 \mu \mathrm{m}$ approximate the Arctic-Okhotsk Sea group. Populations of the east and center of the Barents Sea are in the transition between the north and south sector populations (Shuvalov 1975). It seems likely that the delineated groups differ in their ecological requirements since copepod size is controlled by temperature and food conditions (Marshall 1949, Deevey 1960, Bogorov 1974). For example, our recent study revealed the presence of 2 genera- tions of $O$. similis in the southern Barents Sea during summer (Dvoretsky 2008). These generations strongly differed in body size, which might be connected with different environmental conditions during spawning periods. In the present study, the population in the southern Barents Sea during the summer appears to be mixed, including $O$. similis individuals of 2 generations, since 2 modal classes (large females $>500 \mu \mathrm{m}$ and small females $<465 \mu \mathrm{m}$ ) were present in the southern part of the Barents Sea (Fig. 2)

On the other hand, low variability in female PL in the White Sea (Fig. 5, Table 3) indicates that a single Oithona similis population exists. Such findings are supported by previous observations (e.g. Shuvalov 1965, Prygunkova 1974). However, a detailed analysis of several morphological characteristics (antennule lengths, number of setae, and relative length of antennules and setae) leads to results that contrast with the cited works, as we demonstrate below.

Our data show a clear negative correlation between water temperature and average PL (Tables 5 \& 6). According to numerous experimental studies, water temperature is a main factor affecting growth and early development in crustaceans (Florkin 1960, Kinne 1970, Koski \& Kuosa 1999, Holste \& Peck 2006). An increase in body size correlated with increase in latitude in the northern hemisphere has been noted previously in other marine copepods, such as in Calanus glacialis, C. finmarchicus (Grainger 1961) and Pseudocalanus spp. (Corkett \& McLaren 1978), when spatially distributed populations occur within a temperature gradient. In the polar regions, there is an increase in body size of animals as one moves northward from the south. In the north, species grow more slowly, live longer, and have larger sizes and lower reproductive 
rates in comparison with congeners in lower latitudes and warmer waters (Clarke 1983). The general biological mechanism underlying marine crustacean size is considered to be an increase in the organisms' cell size in a low temperature environment (McLaren et al. 1988, Timofeev 2000). A similar pattern has been reported for other marine crustaceans. The body lengths and the carapace spine lengths of zoeae of the Dungeness crab Cancer magister collected from Alaskan waters $\left(3\right.$ to $5^{\circ} \mathrm{C}$ ) were significantly larger than those of zoeae from Californian waters (10 to $12^{\circ} \mathrm{C}$ ) (Shirley et al. 1987). The authors also noted that the size and relative lengths of extremities and appendages were commonly variable along latitudinal gradients, and that the variation was due to a nongenetic alteration of the phenotype and might have been the result of environmental factors, especially temperature. In the present study, very little of the variance in any of the Oithona similis morphological parameters in the Barents Sea was explained by salinity (Table 6, Fig. 7). Thus, our data suggests that temperature was the main factor that determined variations in the PL of $O$. similis in the Barents Sea.

In the White Sea, water salinity was better correlated with the body sizes of Oithona similis than in the Barents Sea (Tables $5 \& 6$, Figs. $7 \& 8$ ). We propose that the high amplitude of the variation in salinity (up to 7 to 8 ) is the main cause of the phenomenon in the White Sea; in the open Barents Sea, the salinity was greater and its range of fluctuation did not exceed 2 to 3 . The influence of salinity on body size is probably responsible for the fact that the smallest $O$. similis were found in the southeastern Barents Sea and in the White Sea, where salinities were low in comparison with the other areas investigated (Table 1). This effect might be explained by energy requirements for osmotic regulation in extreme salinity regimes (Gaudy et al. 2000, Isla \& Perissinotto 2004). We suggest that $O$. similis body size variation along the south-north axis may be explained by water temperature and salinity variations in the Barents and White Seas, respectively.

Environmental variables and the biological needs of species probably determine the relative importance of each factor under different conditions. However, separation and/or integration of the influences of various factors that act contemporaneously are problematic in field studies (Riccardi \& Mariotto 2000). The morphological characteristics of adults, such as the PL of Oithona similis, are the result of the integrated effect of a series of changeable environmental variables (including temperature, salinity and food levels) during the development of the copepods. In the present study, we correlated the summer temperature and salinity with PL. We suggest that the summer values adequately reflected annual temperature and salinity regimes and may be used to estimate their effects on copepod morphology.

Many studies have shown that food levels play a significant role in the growth and development of copepods (e.g. Shreeve et al. 2002, Hirst \& Bunker 2003). On the other hand, water temperature has been shown to be the main factor substantially explaining variances in the growth and development rates of the copepod Calanus chilensis in northern Chile, with no need to invoke food and body size effects (Giraldo et al. 2006). In our study, we did not see a significant relationship between food levels (Table 1) and Oithona similis body size and morphological characteristics (Tables $5 \& 6$ ). It is worth noting that many of the studies dedicated to the problem of the food effect on copepods have been conducted under controlled environmental conditions (Koski et al. 1998, Koski \& Kuosa 1999). In addition, hydrological conditions during such mesocosm investigations are favorable for copepod development (e.g. Hygum et al. 2000). Phytoplankton concentration seems to assume a primary role under certain spatial or temporal conditions when there is food limitation (Ban 1994), or if temperature has a narrow range of variation (Deevey 1960). For example, food was the main limiting factor for $C$. finmarchicus under optimal temperature and salinity (e.g. Hygum et al. 2000). In contrast, Lee et al. (2003) found that temperature was the main determining factor of Pseudocalanus newmani development time and somatic growth at satiating food conditions. Furthermore, most studies examine individuals of a single population since there may be differences in food requirements between populations from different regions. In our study, chlorophyll a levels probably had less effect on prosome variation in comparison with the main environmental variables (temperature and salinity). In the northern Barents Sea, there is scarcity of food (phytoplankton concentration) during extended periods ( 7 to $8 \mathrm{mo}$ ), yet the sizes of $O$. similis were larger; in the southern part of the Barents Sea and in the White Sea, $O$. similis individuals were smaller despite the favorable food conditions. If the food conditions are the main determinants of body sizes, $O$. similis should have had larger PL in the regions where concentrations of food were higher. $O$. similis can tolerate a wide range of environmental variability due to their adaptations, such as those in respiration rate and feeding strategy (omnivory) (Atkinson 1996, Nakamura \& Turner 1997, Castellani et al. 2005). Furthermore, in the southwestern Barents Sea, which is affected by river run-off, there is a high concentration of nutrients, detritus, and consequently, of phyto- and microzooplankton, considered to be the main food resources for omnivore copepods; here we observed the smallest sizes of $O$. similis. A similar result was reported by 
Kobari et al. (2003) who studied the geographical variations in the PL and body weight of Neocalanus copepods ( $N$. cristatus, $N$. plumchrus and $N$. flemingeri) in the North Pacific. They found that temperature was a more important environmental factor than chl a concentration. Thus, we may also assume that hydrological conditions have a stronger effect on $O$. similis morphology than food levels. Our assumption is also supported by findings in which the sizes of $O$. similis were quite similar in zones with different nutrient conditions (Castellani et al. 2007)

\section{Variation in morphological characteristics}

There is a considerable amount of data concerning the morphology of copepods. However, most of the information refers to appendages and mouth parts (Fleminger 1967, Vyshkvartzeva 1977). Much less is known about the variability of copepod antennules. Antennae serve to maintain the position of Oithona similis in the water column. In addition, they have special sensory structures and play an important role in males during copulation (Shuvalov 1980). The organization of external organs (antennules and appendages) is assumed to have an adaptative significance in animals and to have undergone selection pressure over a long period of time (McLaughlin 1979). We found definite variations in morphological characteristics among the study areas (Table 3, Figs. 3 \& 5). According to the results of discriminant analyses, 3 and 4 morphological groups can be delineated in the Barents and White Seas, respectively (Fig. 6). In the first case, the 3 subpopulations are similar to the morphological forms distinguished by Shuvalov (1980). In the second case, only slight differences in the body length of $O$. similis were found in previous studies, suggesting the presence of a single population in the White Sea (Shuvalov 1965, Prygunkova 1974). However, the definite differences in other morphological characteristics suggest the presence of 4 distinct groups in the present study. Additional investigations are needed to determine which interpretation is correct. Shuvalov $(1965,1980)$ studied variations in $O$. similis total length only and Prygunkova (1974) previously investigated the biology of the species, including its reproductive characteristics and life cycle parameters, in the Chupa inlet (western part of the White Sea). We may assume only one population of $O$. similis in the White Sea if the basic reproductive parameters (mean diameter of eggs, eggs per sac, egg production rate, specific egg production rate) are similar across the region (see e.g. Castellani et al. 2007). However, additional research is necessary to test this idea. At present, we believe that the observed local variations in body length and other morphological characteristics of O. similis, and the suggested presence of 4 different groups in the White Sea, are probably caused by environmental conditions, especially by variations in water salinity.

We propose that spatial variations in absolute and relative antennule and setae lengths might be adaptive for Oithona similis in the Barents and White Seas for several reasons. First, it is very important to have a high relative surface area of appendages and other morphological structures in order to maintain neutral buoyancy (Landry 1980). Water density is known to be reduced if temperature increases and/or salinity decreases. For example, we observed a decrease in antennule length, number and length of setae, and relative antennule length from the south to the north along a temperature gradient in the Barents Sea. It is possible that the lower water density in the south due to the higher temperature levels requires a higher degree of setation and larger antennules to maintain neutral buoyancy. Similarly, antennule lengths and the degree of setation were higher in regions in the White Sea where lower salinity levels, and consequently, lower water density, were observed. Our data are similar to those for other members of the Oithonidae (Shuvalov 1965, 1975). Shuvalov showed that the relative antennule length in Oithona atlantica and the degree of setation in O. plumifera antennules increased from the south to the north. Second, intra- and interspecific relationships might also have a profound impact on the development of morphological differences in O. similis. Morphological structures are likely to play an important role in the recognition of conspecific individuals. In an experimental study, Drits \& Semenova (1985) have shown that $O$. similis did not prey on conspecific nauplii under different food conditions. In addition, it is thought that the system of setae on the antennules is involved in the detection of approaching predators, forming the main component of the mechano-sensory early-warning system of all copepods (Boxshall \& Huys 1998). We also suppose that the sex structure of $O$. similis populations may have an influence on antennule organization, especially in males. Male antennules are typically specialized for grasping the female during mating, with the articulation forming a geniculation with associated secondary segmental fusions and setal modifications (Boxshall \& Huys 1998). Males with more highly segmented antennules would probably have some advantage during copulation. Third, antennules and setae are directly involved in feeding behavior. $O$. similis has been established to be omnivorous (Nakamura \& Turner 1997, Castellani et al. 2005). Prey capture by copepods depends primarily on speed of movement, which is directly related to the organization of swimming structures, including antennules (Landry et al. 1985). 
Thus, a complex of environmental variables (temperature, salinity, nutrient concentrations, turbidity and current regimes) and biological factors (food, predators and competition) is responsible for body organization and morphology in Oithona similis. Nevertheless, we believe hydrological conditions are the major factors determining intrapopulation differences in morphological structures. These factors primarily affect all others including food items exploited by this species and the presence of its predators and competitors.

\section{CONCLUSION}

Thus, we can conclude that Oithona similis specimens differed considerably in morphological characteristics such as body size and relative antennule and setae lengths. More large individuals were observed in the Barents than in the White Sea. Through the analysis of morphological parameters over a wide spatial scale, the present study has shown that 3 groups of $O$. similis can be delineated within the Barents Sea and 4 groups can be distinguished in the White Sea. Hydrological conditions were associated with the morphological variations observed among the copepods. Morphological characteristics and body size were strongly correlated with temperature in the Barents Sea; in the White Sea these parameters were more closely related to salinity. Thus, morphological variability in O. similis is likely an adaptive response to spatial variation in environmental factors.

Acknowledgements. We thank D. V. Moiseev for providing hydrological data; the captains and crews of RV 'Dalniye Zelentsy'; and A. A. Oleiynik, E. A. Garbul and V. V. Larionov for help with sampling. We also especially thank J. A. Nienow (Valdosta State University, USA) for help in correcting the English; and W. Peterson (contributing editor) and 3 anonymous reviewers for their valuable comments that improved the manuscript.

\section{LITERATURE CITED}

Atkinson A (1996) Subantarctic copepods in an oceanic, low chlorophyll environment: ciliate predation, food selectivity and impact on prey populations. Mar Ecol Prog Ser 130: 85-96

Ban S (1994) Effect of temperature and food concentration on postembryonic development, egg production and adult body size of calanoid copepod Eurytemora affinis. J Plankton Res 16:721-735

Berger VY, Naumov AD (2000) General features of the White Sea. Ber Polarforsch 395:3-9

Bobrov YA (1985) Primary production. In: Matishov GG (ed) Life and its existence in the Barents Sea pelagic zone. KSC RAS Press, Apatity, p 110-126 (in Russian)

Bobrov YA, Maksimov MP, Savinov VM (1995) Primary production of phytoplankton. In: Scarlato OA (ed) White Sea. Biological resources and problems of their rational explorations. Part I. Sankt Petersburg, p 92-114 (in Russian)
Bogorov VG (1974) Plankton of the World Ocean. Nauka Press, Moscow (in Russian)

Boitsov VD (2006) Variability temperature in the Barents Sea and its forecasting. PINRO Press, Murmansk (in Russian)

Boxshall GA, Huys R (1998) The ontogeny and phylogeny of copepod antennules. Philos Trans R Soc Lond B Biol Sci 353:765-786

Calow P (1977) Ecology, evolution and energetics: a study in metabolic adaptation. Adv Ecol Res 10:1-62

Castellani C, Irigoien X, Harris RP, Lampitt RS (2005) Feeding and egg production of Oithona similis in the North Atlantic. Mar Ecol Prog Ser 288:173-182

Castellani C, Irigoien X, Harris RP, Holliday NP (2007) Regional and temporal variation of Oithona spp. biomass, stage structure and productivity in the Irminger Sea, North Atlantic. J Plankton Res 29:1051-1070

Clarke A (1983) Life in cold water: the physiological ecology of polar marine ectotherms. Oceanogr Mar Biol Annu Rev 21:341-453

Corkett CJ, McLaren IA (1979) The biology of Pseudocalanus. Adv Mar Biol 15:1-231

Deevey GB (1960) Relative effects of temperature and food on seasonal variations in length of marine copepods in some eastern American and western European Waters. Bull Bingham Oceanogr Coll 17:54-85

Dobrovolskiy AD, Zalogin BS (1982) The seas of the USSR. Moscow State University Press, Moscow (in Russian)

Drits AV, Semenova TN (1985) Experimental investigation of the feeding of Oithona similis Claus. Oceanology (Mosc) 24:755-759

Druzhkov NV, Kuznetsov LL, Baytaz ON, Druzhkova EI (1997) Seasonal cyclic processes in North Europe nearshore pelagic ecosystems (Based on example of Central Murman, the Barents Sea). In: Matishov GG (ed) Plankton of west Arctic seas. KSC RAS Press, Apatity, p 145-178 (in Russian)

Druzhkova EI (2008) Peculiarities of nanophytoplankton spatial distribution in the coastal zone of Novaya Zemlya and Franz Josef Land. In: Matishov GG, Tarasov GA (eds) Nature of the shelf and archipelagos of the European Arctic. Proc Int Scientific Conf, Murmansk, November 9-11, 2008. GEOS Press, Moscow, p 120-123 (in Russian)

Dvoretskii VG (2007) Characteristics of the Oithona similis (Copepoda: Cyclopoida) in the White and Barents Seas. Dokl Biol Sci 414:223-225

Dvoretsky VG (2008) Distribution and reproductive characteristics of Oithona similis (Copepoda, Cyclopoida) in the southern part of the Barents Sea. Probl Fish 9:66-82 (in Russian)

Fedorov VD, Bobrov YA (1977) Seasonal variations of selected parameters of the phytoplankton production in the White Sea. Vestn MGU, Ser Biol 1:104-112 (in Russian)

Fleminger A (1967) Taxonomy, distribution and polymorphism in the Labidocera jollae group with remarks on evolution within the group (Copepoda: Calanoida). Proc US Nat Mus 120:1-61

Florkin M (1960) Ecology and metabolism. In: Waterman TH (ed) The physiology of Crustacea, Vol 1. Metabolism and growth. Academic Press, New York, p 395-410

Fomin OK (1978) Some temporal characteristics of zooplankton in the coastal Murman waters. In: Bryazgin VF (ed) Regularities of biological production in the Barents Sea. Kola Branch AS USSR Press, Apatity, p 72-91 (in Russian)

> Gaudy R, Cervetto G, Pagano M (2000) Comparison of the metabolism of Acartia clausi and A. tonsa: influence of temperature and salinity. J Exp Mar Biol Ecol 247:51-65

Giraldo A, Escribano R, Marm V (2006) A field test of temperature effects on ecophysiological responses of copepodid Calanus chilensis during coastal upwelling in northern Chile. Cont Shelf Res 26:1307-1315 
Grainger EH (1961) The copepod Calanus glacialis Jaschnov and Calanus finmarchicus (Gunnerus) in Canadian arcticsubarctic waters. J Fish Res Board Can 18:663-678

Hirst AG, Bunker AJ (2003) Growth of marine planktonic copepods: global rates and patterns in relation to chlorophyll a, temperature, and body weight. Limnol Oceanogr 48:1988-2010

Holste L, Peck MA (2006) The effects of temperature and salinity on egg production and hatching success of Baltic Acartia tonsa (Copepoda: Calanoida): a laboratory investigation. Mar Biol 148:1061-1070

Hygum BH, Rey C, Hansen BW, Tande K (2000) Importance of food quantity to structural growth rate and neutral lipid reserves accumulated in Calanus finmarchicus. Mar Biol 136:1057-1073

Ingvaldsen RB, Aspline L, Loeng H (2004) The seasonal cycle in the Atlantic transport to the Barents Sea during the years 1997-2001. Cont Shelf Res 24:1015-1032

Isla JA, Perissinotto R (2004) Effects of temperature, salinity and sex on the basal metabolic rate of the estuarine copepod Pseudodiaptomus hessei. J Plankton Res 26:579-583

Kobari T, Tadokoro K, Shiomoto A, Hashimoto S (2003) Geographical variations in prosome length and body weight of Neocalanus copepods in the North Pacific. J Oceanogr 59: $3-10$

Khromov VM, Fedorov VD (1970) Seasonal changes of primary productivity in the White Sea. Vestn MGU 5:23-26 (in Russian)

Kinne O (1970) Temperature: animals - invertebrates. In: Kinne O (ed) Marine ecology: environmental factors, Vol 1, Part I. Wiley-Interscience, London, p 407-514

$>$ Koski M, Kuosa H (1999) The effects of temperature, food concentration and female size on the egg production of the planktonic copepod Acartia bifilosa. J Plankton Res 21: 1779-1789

Koski M, Klein Breteler W, Schoft N (1998) Effect of food quality on rate of growth and development of the pelagic copepod Pseudocalanus elongatus (Copepoda, Calanoida). Mar Ecol Prog Ser 170:169-187

Landry MR (1980) Detection of prey by Calanus pacificus: implications of the first antennae. Limnol Oceanogr 25: 545-549

Landry MR, Lehner-Fournier JM, Fagerness VL (1985) Predatory feeding behavior of the marine cyclopoid copepod Corycaeus anglicus. Mar Biol 85:163-169

Lee HW, Ban S, Ikeda T, Matsuishi T (2003) Effect of temperature on development, growth and reproduction in the marine copepod Pseudocalanus newmani at satiating food condition. J Plankton Res 25:261-271

Marshall SM (1949) On the biology of the small copepods in Loch Striven. J Mar Biol Assoc UK 28:45-122

Matishov G, Zuyev A, Golubev V, Adrov N and others (2004) Climatic atlas of the Arctic Seas 2004. I. Database of the Barents, Kara, Laptev, and White Seas - oceanography and marine biology. NOAA Atlas NESDIS 58. US Government Printing Office, Washington, DC

- McLaren IA, Sevigny JM, Corkett CJ (1988) Body size, development rates, and genome size among Calanus species. Hydrobiologia 167-168:275-284

McLaughlin PA (1979) Comparative morphology of recent Crustacea. W. H. Freeman, San Francisco, CA

Mordasova NV, Wentzel MV (1994) Features of distribution of phytopigments and phytoplankton biomass in the White Sea in summer season. In: Sapozhnikov VV (ed) Complex studies of the White Sea ecosystem. VNIRO Press, Moscow, p 83-94 (in Russian)
Nakamura Y, Turner JT (1997) Predation and respiration by the small cyclopoid copepod Oithona similis: How important is feeding on ciliates and heterotrophic flagellates? J Plankton Res 19:1275-1288

Naumov AD, Fedyakov VV (1991) Peculiarities of hydrological conditions of the north part of the White Sea. Proc Zool Inst 233:13-26 (in Russian)

Nielsen TG, Møller EF, Satapoomin S, Ringuette M, Hopcroft RR (2002) Egg hatching rate of the cyclopoid copepod Oithona similis in Arctic and temperate waters. Mar Ecol Prog Ser 236:301-306

Pedersen G, Tande KS, Nilssen EM (1995) Temporal and regional variation in the copepod community in the central Barents Sea during spring and early summer 1988 and 1989. J Plankton Res 17:263-282

Prygunkova RV (1974) Certain peculiarities in the seasonal development of zooplankton in the Chupa Inlet of the White Sea. Explor Fauna Sea 13:4-55 (in Russian)

Raymont JEG (1980) Plankton and productivity in the ocean, 2. Zooplankton, 2nd edn. Pergamon Press, Oxford

- Riccardi N, Mariotto L (2000) Seasonal variations in copepod body length: a comparison between different species in the Lagoon of Venice. Aquat Ecol 34:243-252

Savinov VM (1992) Spatial distribution of chlorophyll and primary production. In: Matishov GG (ed) The Barents Sea phytoplankton. KSC RAS Press, Apatity, p 52-63 (in Russian)

Savinov VM, Bobrov YuA (1995) Chlorophyll and primary production. In: Matishov GG (ed) Environments and ecosystems of the Novaya Zemlya (Archipelago and shelf). KSC RAS Press, Apatity, p 41-46

Schauer U, Loeng H, Rudels B, Ozhigin VK, Dieck W (2002) Atlantic water flow through the Barents and Kara Seas. Deep-Sea Res I 49:2281-2298

Shirley SM, Shirley TC, Rice SD (1987) Latitudinal variation in the Dungeness crab, Cancer magister: zoeal morphology explained by incubation temperature. Mar Biol 95: 371-376

Shreeve RS, Ward P, Whitehouse MJ (2002) Copepod growth and development around South Georgia: relationships with temperature, food and krill. Mar Ecol Prog Ser 233: 169-183

Shuvalov VS (1965) Geographical size variability and some aspects of biology of Oithona similis Claus (Copepoda, Cyclopoida) in the White Sea (Kandalaksha Bay). Okeanologia 5:338-347 (in Russian)

Shuvalov VS (1975) Geographical variability of some species of the family Oithonidae (Copepoda, Cyclopoida). In: Zvereva ZA (ed) Geographical and seasonal variability of marine plankton. Keter Publishing House Jerusalem, p 169-185

Shuvalov VS (1980) Copepod cyclopoids of the family Oithonidae of the World Ocean. Nauka Press, Leningrad (in Russian)

Timofeev SF (2000) Ecology of the marine zooplankton. Murmansk State Pedagogical Institute Press, Murmansk (in Russian)

Vyshkvartzeva NV (1977) The functional morphology of mouthparts of the species Calanus s.l. (Copepoda, Calanoida). II. The functioning of the mouth apparatus and the feeding. Explor Fauna Sea 19:5-28 (in Russian)

Wiktor J, Zajaczkowski M (1992) Suspended matter and phytoplankton in Tikhaia Bay, summer 1991. In: Gjertz I, Morkved B (eds) Environmental studies from Franz Josef Land with emphasis on Tikhaia Bay, Hooker Island. Norsk Polarinstitutt, Meddelser, p 14-18

Zaks L (1976) The statistical estimation. Statistics Press, Moscow (in Russian)

Submitted: May 27, 2008; Accepted: February 18, 2009

Proofs received from author(s): June 1, 2009 